of the UFC's research support should be transferred to the research councils.

Money would then reach the best researchers, he says, irrespective of whether they work in universities or polytechnics. This would mean a reduction in some universities' incomes, but Burlin says none should be faced with worse than a budget shrinking at five per cent a year - a rate of contraction already experienced by a number of polytechnics.

This view is not confined to the polytechnics. John Ziman, director of the Science Policy Support Group, an independent body dependent on research council support, says the current distribution of research funds confuses British science policy.

He remarks that there is no audit of the UFC's research spending after it reaches the universities, so that UFC research money may be diverted into teaching, for example.

Some research council officials say privately that further transfers from the UFC's budget are possible now the process has begun. But switching money from the UFC is not the only way to direct more public research spending into the polytechnics. Another approach would be to merge UFC and PCFC, allowing UFC's research funds to be distributed across all British higher education institutions.

The British Labour party has made the relaxation of the 'binary divide' a policy goal. Higher education spokesman Andrew Smith says that PCFC and UFC would be merged "in the early part" of a Labour administration, but that the allocation of research money by the merged body has yet to be determined.

Closer links between PCFC and UFC are likely whatever the colour of the next government; the two councils move into the same building in Bristol later this year. But even if there is a full merger, the pressure for value for money may focus research spending into fewer institutions, meaning that few polytechnics would benefit, and that university budgets would shrink.

Yet further reductions in the universities' research income from the UFC will meet strong resistance. John Ashworth, director of the London School of Economics and chairman of a joint CVCP/ Committee of Directors of Polytechnics working group on higher education finance, says that decisions on research management are best made in the institutions where research is carried out. Transferring the majority of the UFC's research spending to the research councils would result in funds being allocated "with the skill and panache of the Soviet Academy of Sciences", he says. He believes the polytechnics should concentrate on providing high-level training, rather than aspiring to be "second-class universities".

Peter Aldhous

\title{
Showdown over overheads?
}

\section{Washington \& San Francisco}

THE glory days of university research in the United States, when the government paid universities to build hundreds of laboratories and keep them running, may be at an end. And the "indirect costs" of academic research are becoming a divisive issue between universities and the government and even within universities.

After decades of reimbursing universities fully for indirect costs, which may include everything from new construction to heating and upkeep, federal science agencies are increasingly paying for just the science and a fraction of related costs. University officials say the trend may turn academic scientists against their administrators and eventually cause the collapse of university research.

Budget pressure and congressional legislation last year forced both the $\mathrm{Na}$ tional Science Foundation and the US Department of Agriculture to reduce payments of indirect costs. Agriculture was told that payments should not exceed 14 per cent of direct research costs, about a quarter of what the average university calculates as its real overhead expense. Now the White House has signalled that the National Institutes of Health (NIH) may have to cut back as well.

The NIH are the largest single source of funds for university-based research and one of the few science agencies still paying full indirect costs. In an internal memorandum to NIH, the White House Office of Management and Budget (OMB) last month sanctioned less than full reimbursement of indirect costs in NIH-funded university research.

The document is NIH's spending authority for the year, saying how much they can spend, and how. Although the language is outwardly harmless "Indirect costs are upper limits", for example - both the academic community and NIH are on full alert.

At an advisory council meeting of the National Institute of General Medical Sciences last week, NIH extramural research director John Diggs described the OMB plan as "shocking". In a subsequent interview, he said that NIH nevertheless remain committed to full support of indirect costs, although "we're in line to have further discussion with OMB".

University representatives are preparing for the worst. Carol Scheman of the American Association of Universities says "virtually every research university has made long-term commitments in the belief that it will be reimbursed ... the collapse of a reliable reimbursement policy would mean a major financial crisis".

University administrators warn that if federal agencies refuse to pay full indirect costs, they may have to recover the money by requiring researchers to include the costs of support services, such as animal facilities, in direct research costs.

Researchers, in turn, worry that grant proposals bloated in this way will disadvantage them in what is already a cutthroat fight for federal research support. Speaking of an "an erosion of trust between faculty and administration", Douglas Kelly of the American Association of Medical Colleges says he is worried about "a coming confrontation".

Meanwhile, Congress has taken up the issue as an example of the misuse of government funds. Disturbed by the increase in the cost of research (the average value of NIH grants has doubled in the past decade, largely because of indirect costs), Representative John Dingell (Democrat, Michigan) has unleashed his staff investigators on Stanford University, which has one of the highest indirect cost rates at 72 per cent. The investigation has found that, among other questionable practices, Stanford improperly included in its administrative overhead payments on a university yacht and furnishings for president Donald Kennedy's residence.

Last week Kennedy announced a threepronged initiative to clear the air. Stanford will hire an outside accounting firm to evaluate the university's accounting methods, appoint an advisory panel to examine research costs and voluntarily withdraw some $\$ 500,000$ of past claims.

Kennedy says that he does not feel that Stanford has been singled out unfairly, although it is certainly "not pleasant" to be put through such an investigation. Perhaps because of the university's high profile and some $\$ 500$ million in indirect cost charges in the past decade, "we just happened to be first", he says.

Dingell's Energy and Commerce oversight subcommittee plans to hold hearings on the subject in February or March. Other universities, including the Massachusetts Institute of Technology, may also be investigated, according to staff member Dennis Fitzgibbons. Dingell's next step, Fitzgibbons says, is to determine what changes in the system are needed. If there are restrictions on the payment of indirect costs, Congress must determine who should decide what is reasonable. NIH could set a maximum reimbursement level, the federal government could draft new regulations on indirect-cost recovery or Congress could limit indirect-cost rates in the appropriations process, as it did last year with the agriculture department.

Kennedy says he cannot predict what will be decided, but he predicts that modifications to the indirect-cost system are on the way.

Christopher Anderson \& Elizabeth Schaefer 